\title{
Metal-based systems allowing the use of scrap to prepare aluminum alloys
}

Yu. N. Mansurov, Director ${ }^{1}$, Professor $^{2}$, e-mail: yulbarsmans@gmail.com

J. U. Rakhmonov, PhD, Postdoctoral Fellow ${ }^{3}$, e-mail: jovid.rakhmonov@gmail.com

A. A. Aksyonov, Professor $^{4}$, e-mail: andreyaksenov@me.com

\author{
${ }^{1}$ Institute of General and Inorganic Chemistry, Academy of Sciences, Tashkent, Uzbekistan. \\ ${ }^{2}$ Tashkent State Transport University, Tashkent, Uzbekistan. \\ ${ }^{3}$ University of Quebec in Chicoutimi, Quebec, Canada. \\ ${ }^{4}$ National University of Science and Technology MISIS, Moscow, Russia.
}

\begin{abstract}
The amount of scrapped structures and components made of aluminum alloys is constantly growing along with the increase in the demand for the use of aluminum alloys in various industrial sectors. Uzbekistan has been showing a trend of developing industrial production at a pace typically observed in highly developed countries. In Uzbekistan, the aluminum alloys are used for widespread applications in construction, engineering, energy, chemistry and chemical technology, etc. Due to lack of primary aluminium production facilities in the country, there is a need for the collection and deep processing of the scrapped parts that have fulfilled their useful life. This practice is well implemented and working well for the collection of parts from Al - Si based alloys, also called silumins. The composition, structure and properties of many secondary silumins, which have found application in mechanical engineering, have been developed and improved. For alloys of the $\mathrm{Al}-\mathrm{Si}$ system, most of research activities focused on property improvement through microalloying as well as improvements in the casting technology and heat treatments. However, it is too early to talk about a systematic approach to improving the operational properties of silumins. This also fully applies to alloys of other systems based on aluminum, for example, Al - Mg alloys, also called magnalias. For Uzbekistan, this is very important, since, as analysis shows, the aluminum alloys of 6XXX family are predominantly used for the construction and building structures. After the development of the first secondary wrought alloy of aluminum with the main alloying element with magnesium, many works were published with the results on improving the composition, structure, properties, processing technologies of secondary magnesia. The published works are notable for the inconsistency of the authors' positions on microalloying systems and the thermal treatment of secondary magnalias. Regarding silumins, all the results are experimental, there is no systematic approach to the development of new and improvement of the properties of existing alloys from scrapped parts. Based on the experimental results, the article proposes an attempt of a systematic approach to the choice of alloy composition, microalloying systems, optimization of the composition of aluminum alloys for industry.
\end{abstract}

Key words: aluminium, magnesium, silicon, impurities, scrap and wastes, secondary alloys

DOI: $10.17580 / \mathrm{nfm} .2020 .02 .07$

\section{Introduction}

$\mathrm{T}$ he research results obtained within the framework of the state scientific and technical programs of Uzbekistan allowed us to develop a scientifically based approach to the creation of new aluminum alloys with a high content of impurities as well as the preparation technology which allows processing scrape metals more effectively and increasing the metal utilization rate due to the use of recycled scrap metal as a raw material. These are parts and structures that have worked out their service life, the main part of which is waste of window production, aircraft construction, and automobile construction. The analysis showed that parts from alloys of 5000 and 6000 series prevail among the waste. It is logical, first, to consider the $\mathrm{Al}-\mathrm{Mg}$ system to improve existing alloys and create new ones, thereby expanding the field of application of aluminum alloys with magnesium being the main alloying element.

The increase in automobile production and launching a powertrain plant in Tashkent to produce engines for local automobile production led to the fact that the share of silumin scrap began to increase in the volume of non-ferrous scrap metal. Therefore, multicomponent alloys based on the $\mathrm{Al}-\mathrm{Si}$ system are also considered in the work to develop a systematic approach and unify the composition of industrial alloys developed by various scientific schools.

The purpose of this work is to study the chemical composition of secondary magnalias and silumins in order to optimize their composition and properties, organize the processing of aluminum scrap metal for the needs of industrial enterprises of Uzbekistan in high-strength cast aluminum alloys.

To achieve the goal, the following tasks were solved:

- the addition levels of alloying elements and impurities in magnalias were optimized;

- on the example of magnalias, the chemical and phase compositions of aluminum alloys alloyed with some rare-earth metals as well as scandium were experimentally studied;

- based on a systematic approach, the composition of industrial silumins has been optimized; 
- recommendations were developed for optimizing the composition of high-strength cast aluminum alloys.

\section{Materials and methods}

In this work, aluminum of grades A7, A5, A0, scrap and secondary alloy according to GOST (State Standart) 1583-73 was used for the manufacture of the model and industrial alloys. Fusible elements were introduced in pure form in foil. Elements with a high melting point were introduced in the form of master alloys, for example, $\mathrm{Al}-10 \% \mathrm{Mn}, \mathrm{Al}-5 \% \mathrm{Fe}, \mathrm{Al}-5 \% \mathrm{Be}$ (all in wt.\%). The components of the charge were introduced into the molten metal at a temperature, ${ }^{\circ} \mathrm{C}$ : 730 (not higher) - smallsized scrap parts; 740-750 - copper, at 700-740 - silicon, 700-740 - master alloys; zinc was introduced before magnesium at the end of the melting process.

The melting temperature of cast aluminum alloys did not exceed $800-830^{\circ} \mathrm{C}$.

When melting aluminum alloys containing magnesium, copper and manganese, the aluminum and silumin were first added into the furnace followed by master alloys and the remaining scrap parts.

Magnesium was introduced after refining at $720-730{ }^{\circ} \mathrm{C}$, after which the alloys were further treated and poured.

When using the return of our own production for the preparation of alloys, the melting order was as follows: melting of pure aluminum and $\mathrm{Al}-$ Be alloys; introduction of the return of own production at $670-700{ }^{\circ} \mathrm{C}$.

The composition of the alloys was monitored using $X$-ray fluorescence analysis (RSFA), and a MagiX crystal diffraction scanning spectrometer (PHILIPS Analytical $X$-Ray, Netherlands).

The microstructure of the alloys was studied by metallographic analysis using a Neopfot-2 light optical microscope (LOM). $X$-ray microspectral, phase analysis, phase identification were carried out using a Tescan Vega 3 XM scanning electron microscope (SEM).

The mechanical properties of the samples were determined according to the interstate standard "Metals. Tensile test methods" - GOST (State Standart) 1497-84 (ISO 6892-84, ST SEV 471-88 with Amendments $1,2,3)$ on the Zwick $Z 250$ universal testing machine and Wilson Wolpert $930 \mathrm{M}$ universal hardness tester.

Calculation and optimization of the composition was performed using the Thermo-Calc software product. To carry out calculations of the phase composition, phase fractions, and solubility of elements in the structural components, the TTAL5 database was used.

\section{Results and discussion}

\section{Alloys of the $\mathrm{Al}-\mathrm{Mg}$ system}

The extensive research on the structure, mechanical and casting properties of $\mathrm{Al}-\mathrm{Mg}$ alloys containing impurities has led to the development of compositions of secondary alloys based on the $\mathrm{Al}-\mathrm{Mg}$ system [1-4]. However, all alloys are developed experimentally, and no systematic work is conducted that would allow developing new alloys and improving the existing ones. This problem can be solved using a software package that includes the development of Thermo-Calc, which allows modelling alloy compositions, calculating phase equilibria, building poly- and isothermal sections, cross-sections of multicomponent metal systems [5].

Using the Thermo-Calc software, several three- and fourcomponent phase diagrams and their poly- and isothermal cross sections were constructed (examples in Fig. 1).
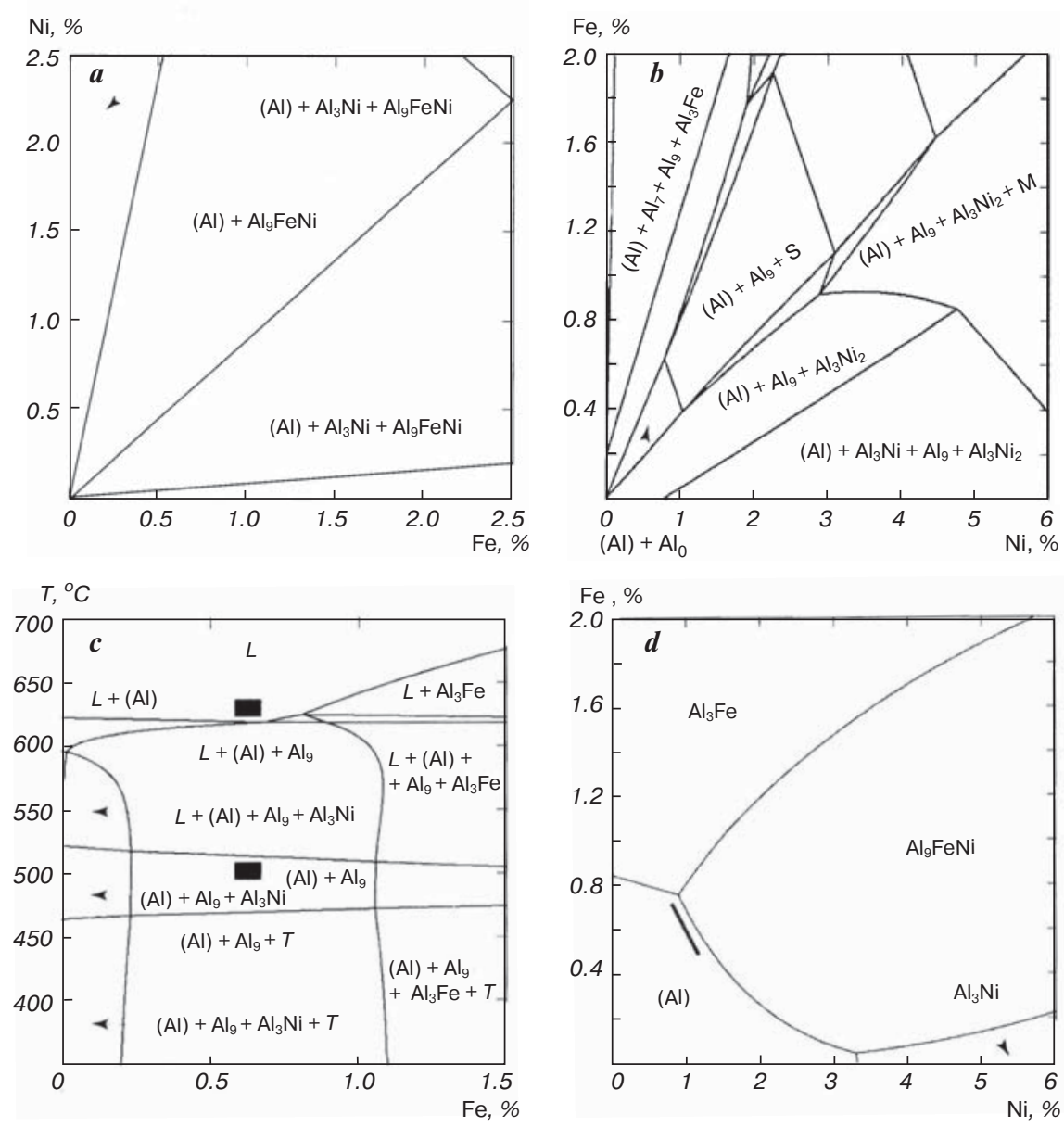

Fig. 1. Examples of multicomponent systems based on aluminum, their sections, built using the Thermo-calc software:

$a-\mathrm{Fe}, \mathrm{Ni}, 4 \% \mathrm{Mg}, 2 \% \mathrm{Zn}$, isothermal cross section at $570{ }^{\circ} \mathrm{C} ; b-\mathrm{Fe}, \mathrm{Ni}, 4 \% \mathrm{Mg}, 2 \% \mathrm{Zn}$, isothermal cross section at $460{ }^{\circ} \mathrm{C} ; c-4 \% \mathrm{Mg}, 2 \% \mathrm{Zn}, 1 \% \mathrm{Ni}, \mathrm{Fe}$, polythermic cross section; $d-\mathrm{Fe}, \mathrm{Ni}, 4 \% \mathrm{Mg}, 2 \% \mathrm{Zn}$, projection liquidus 
Based on the analysis of phase equilibria, the concentration range of the main alloying components, small additives, and the boundary content of impurities was determined. The choice of concentrations of chemical elements is based on obtaining a favourable structure of alloys with a high content of impurities. In this case, first, they considered the possibility of neutralizing the most harmful impurities: iron and silicon. It was necessary to find the possibility of modifying the structure by changing the concentration of chemical elements existing in the alloys. It did not matter whether the chemical element in the alloy was in the form of an impurity, a small additive, or the main alloying element. The main point is that the element makes a change in the morphology of the phases and their characteristics. The choice of multicomponent systems is, first, based on the composition of alloys of the 5XXX and 6XXX series, as well as on the State standard GOST (State Standart) 1639-2009 "Scrap and waste of non-ferrous metals and alloys. General technical conditions" - consumers of aluminum alloys are guided by the processing of scrap and waste. In the work, more than 30 systems with elements included in the composition of alloys of the above series and standard have been calculated, constructed, studied.

As examples, Fig. 1 shows nickel systems that strongly affect the morphology of iron-containing phases. In addition, nickel is found in scrap aluminum alloys. The main task of the constructed systems is to establish the boundary values of alloying elements, additives, impurities.

To determine the main composition, we chose a region with $4.5-7 \% \mathrm{Mg}$, where, in accordance with the results obtained in this work, as well as with known information from the literature [6-8], it is possible to obtain the optimal combination of mechanical, casting and corrosion properties after the heat treatment, as well as good machinability by cutting and weldability. A higher magnesium content leads to an increase in the $\beta$-phase, which causes embrittlement and a decrease in the mechanical properties of cast alloys.

The increased silicon content $(0.6-1.5 \%)$ contributes to the improvement of casting properties. However, its concentration has been found to be limited to $1.5 \%$. A high concentration of silicon reduces the mechanical properties of the alloy even in the quenched state after high-temperature homogenization. Up to this limit, the harmful effect of silicon can be neutralized by heating for quenching - the phase changes its morphology: first, the phase particles are fragmented and then coagulated. In this case, a large volume fraction of particles of the $\mathrm{Mg}_{2} \mathrm{Si}$ phase contributes to a decrease in $\sigma_{U T S}, \sigma_{0.2}$, and, especially, $\delta$. It should be noted that the ratio of magnesium and silicon, as established earlier [5-7, 9, 13], should be preserved in the ratio when all silicon is bound into the $\mathrm{Mg}_{2}$ Si phase.

If the alloy contains up to $1 \% \mathrm{Fe}$, it is possible to neutralize the harmful effect of inclusions of iron-containing intermetallic compounds. This is achieved by changing the morphology of the harmful phases by alloying the phase [9-11]. Needle, lamellar or branched iron intermetallics acquire a compact, rounded shape when small additions of beryllium, cobalt and nickel are introduced into the alloy. With an iron content of more than $1 \%$, it is also possible to change the shape of the needles and plates of the glandular phases, but due to the increase in the volume fraction of even precipitates that are favorable in shape, the mechanical properties remain low.

The addition of iron in the proposed alloy $(\geq 0.4 \%)$, according to literature [12-14], improves machinability and facilitates the separation of the casting from the mold during casting and die casting.

The alloy, which is optimal in structure, differs from the previously studied aluminum-magnesium alloys in the high content of silicon impurities (up to 1.5\%), zinc (up to $1.5 \%$ ), iron (up to $1 \%$ ), copper (up to $0.8 \%$ ), smaller tin $0.1 \%$ ), lead (up to $0.15 \%$ ). Nickel (as well as beryllium, cobalt) can be introduced into the alloy, as a modifier of iron-containing phases, in an amount of up to $0.3 \%$. The amount of zinc, copper, tin, lead is taken in accordance with their content in scrap metal. Of all the phase diagrams, the nickel example in Fig. 1 is given insofar as it is also contained in scrap metal and has been found to be effective in changing the morphology of the ironcontaining phases.

The microstructures of the studied, compositionally optimized alloys with various component contents in as-cast states are shown in Fig. 2.

Fig. 3. shows the microstructure of the same alloys as in Fig. 2, but after heat treatment.

An analysis of the microstructure showed that, with the highest content of elements, a new phase appears in the alloy in the form of faceted large crystals (indicated by arrows in Fig. 2, $c$ and Fig. 3, c). According to the results of the micro $X$-ray phase analysis of the alloy in the cast state (Table 1), it was found that in $\alpha-\mathrm{Al}$ solid solution, zinc is completely soluble, while $\mathrm{Cu}-$ up to $0.3 \%, \mathrm{Mn}-$ up to $0.2 \%$ and $\mathrm{Mg}$ is up to $\sim 5 \%$.

Silicon is fully and magnesium is partially (approximately $0.7-0.9 \%$ ) bound to magnesium silicide $\left(\mathrm{Mg}_{2} \mathrm{Si}\right)$. Copper, in the same amount as in $\alpha-\mathrm{Al}$ solid solution, is in $\mathrm{FeAl}_{3}$ phase. Manganese and nickel are significantly soluble in the $\mathrm{FeAl}_{3}$ phase and bind iron to the $(\mathrm{FeMn})$ $\mathrm{Al}_{6}$ and $\mathrm{FeNiAl}_{9}$ phases. Moreover, at a maximum content of components in the alloy, primary crystals of (FeMn) $\mathrm{Al}_{6}$ phase form during solidification, the composition of which practically does not differ from previously studied particles of the same phase. A detailed phase analysis of the alloys is presented in Table 1 and below in the text.

Tin and lead together with the $\mathrm{Mg}_{2} \mathrm{Si}$ phase form a structural component ( $\mathrm{Mg}, \mathrm{Si}, \mathrm{Sn}, \mathrm{Pb}$ ). To quantify the effect of phases on the mechanical properties, some parameters of the microstructure of the alloy were determined, namely, the volume fraction $-Q$, the specific interphase surface $-S$, the linear size $-l$, and the phase shape coefficient $-F$ (Table 2$)$. 

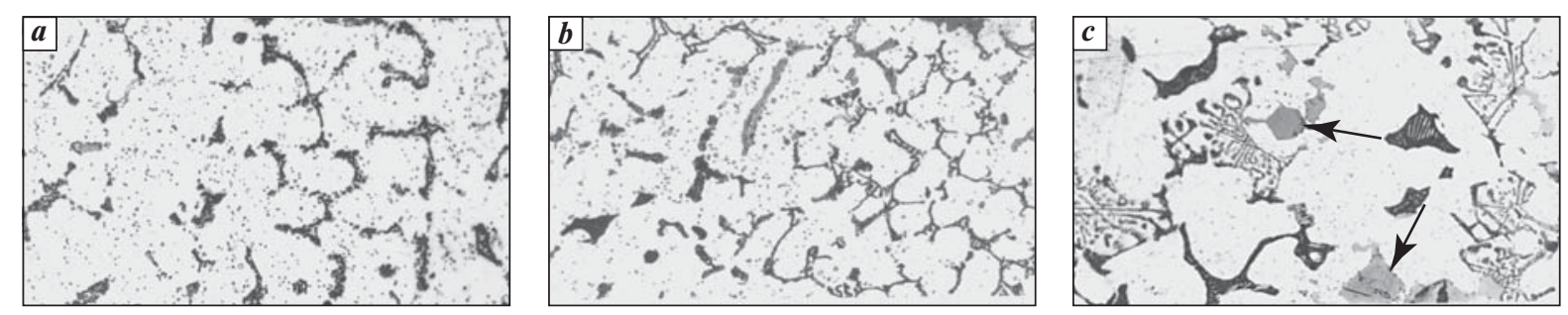

Fig. 2. Microstructure of an aluminum alloys with a high content of impurities, cast state, $\times 400$

$a-\mathrm{Al}+4.5 \% \mathrm{Mg}+0.6 \% \mathrm{Si}+0.4 \% \mathrm{Fe}+0.1 \% \mathrm{Cu}+0.6 \% \mathrm{Zn}+0.01 \% \mathrm{Sn}+0.01 \% \mathrm{~Pb}+0.2 \% \mathrm{Mn}+0.05 \% \mathrm{Ni}$

$b-\mathrm{Al}+6 \% \mathrm{Mg}+1 \% \mathrm{Si}+0.8 \% \mathrm{Fe}+0.5 \% \mathrm{Cu}+1 \% \mathrm{Zn}+0.05 \% \mathrm{Sn}+0.08 \% \mathrm{~Pb}+0.4 \% \mathrm{Mn}+0.15 \% \mathrm{Ni}$

$c-\mathrm{Al}+7 \% \mathrm{Mg}+1.5 \% \mathrm{Si}+1 \% \mathrm{Fe}+0.8 \% \mathrm{Cu}+1.5 \% \mathrm{Zn}+0.1 \% \mathrm{Sn}+0.15 \% \mathrm{~Pb}+0.6 \% \mathrm{Mn}+0.3 \% \mathrm{Ni}$
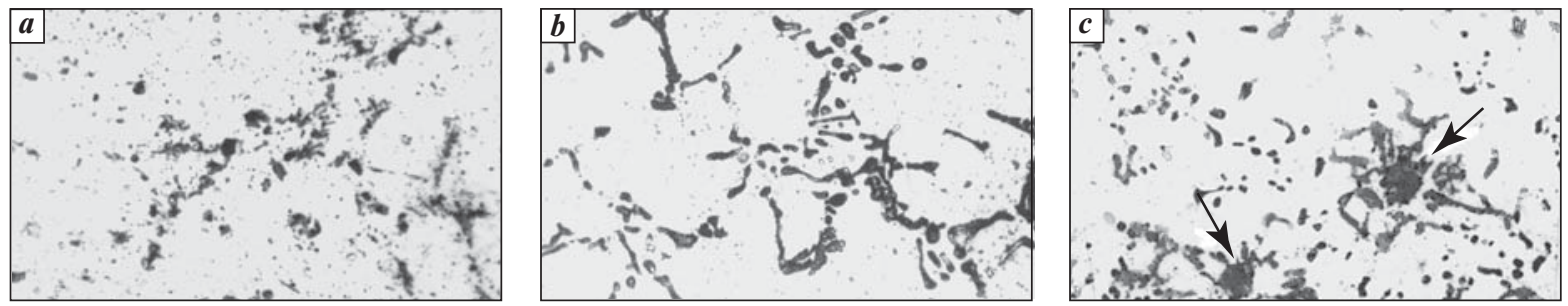

Fig. 3. Microstructure of an aluminum alloys with a high content of impurities after heat treatment, $\mathrm{x} 400$ :

$a-\mathrm{Al}+4.5 \% \mathrm{Mg}+0.6 \% \mathrm{Si}+0.4 \% \mathrm{Fe}+0.1 \% \mathrm{Cu}+0.6 \% \mathrm{Zn}+0.01 \% \mathrm{Sn}+0.01 \% \mathrm{~Pb}+0.2 \% \mathrm{Mn}+0.05 \% \mathrm{Ni}$

$b-\mathrm{Al}+6 \% \mathrm{Mg}+1 \% \mathrm{Si}+0.8 \% \mathrm{Fe}+0.5 \% \mathrm{Cu}+1 \% \mathrm{Zn}+0.05 \% \mathrm{Sn}+0.08 \% \mathrm{~Pb}+0.4 \% \mathrm{Mn}+0.15 \% \mathrm{Ni}$

$c-\mathrm{Al}+7 \% \mathrm{Mg}+1.5 \% \mathrm{Si}+1 \% \mathrm{Fe}+0.8 \% \mathrm{Cu}+1.5 \% \mathrm{Zn}+0.1 \% \mathrm{Sn}+0.15 \% \mathrm{~Pb}+0.6 \% \mathrm{Mn}+0.3 \% \mathrm{Ni}$

Table 1

The results of $X$-ray phase analysis of an aluminum alloy with a high content of impurities in as-cast alloy

\begin{tabular}{|l|c|c|c|c|c|c|c|c|c|c|}
\multirow{2}{*}{\multicolumn{1}{c}{ Phases }} & \multicolumn{10}{c|}{ Content of elements, wt.\% } \\
\cline { 2 - 20 } & $\mathrm{Mg}$ & $\mathrm{Si}$ & $\mathrm{Fe}$ & $\mathrm{Cu}$ & $\mathrm{Zn}$ & $\mathrm{Sn}$ & $\mathrm{Pb}$ & $\mathrm{Mn}$ & $\mathrm{Ni}$ & $\mathrm{Al}$ \\
\hline$\alpha-\mathrm{Al}$ & 1.6 & - & - & 0.3 & 1.5 & - & - & 0.2 & - & other \\
\hline$(\mathrm{Mg}, \mathrm{Si}, \mathrm{Sn}, \mathrm{Pb})$ & $41.7-62.1$ & $23.1-34.1$ & - & - & - & $2.4-17.8$ & $1.5-11.3$ & - & - & - \\
\hline$(\mathrm{Al}, \mathrm{Fe}, \mathrm{Mn}, \mathrm{Ni}, \mathrm{Cu})$ & - & - & $2.5-37$ & $0.1-2.5$ & - & - & - & $0.5-9$ & $0.5-28$ & other \\
\hline $\mathrm{S}\left(\mathrm{Al}_{2} \mathrm{CuMg}\right)$ & 6.8 & - & - & 16.2 & - & - & - & - & - & other \\
\hline$\beta\left(\mathrm{Al}_{3} \mathrm{Mg}_{2}\right)$ & 35.3 & - & - & - & - & - & - & - & - & other \\
\hline
\end{tabular}

Apparently, an unambiguous linear correlation between the particle size of the excess phases and their specific interphase surface does not exist. Probably, this relationship has a more complex nature. Moreover, the linear size, $l$, measured in the section plane, does not reflect the morphology of phases in 3D. At the same time, the volume fraction of the phases con-

Table 2.

The results of metallographic analysis of aluminum alloy with a high content of impurities, in as-cast state

\begin{tabular}{|c|c|c|c|c|c|}
\hline Phase & $Q$, vol. \% & $\begin{array}{c}S \\
\mathrm{~mm}^{2} / \mathrm{mm}^{-3}\end{array}$ & $I, \mu \mathrm{m}$ & $F$ & Notes \\
\hline$\alpha(\mathrm{Al})$ & $91.15-84.8$ & $50-101$ & $24.4-19.8$ & $0.7-0.8$ & \multirow{5}{*}{$\begin{array}{l}\text { The range of } \\
\text { values of } Q, S, I- \\
\text { is given for alloys } \\
\text { with a maximum } \\
\text { concentration of } \\
\text { components }\end{array}$} \\
\hline (Mg, Si, Sn, Pb) & $4.7-6.6$ & $391-496$ & $3.03-5.11$ & $0.1-0.2$ & \\
\hline (Al, Fe, Mn, Ni, Cu) & $2.0-4.4$ & $227-370$ & $5.4-6.1$ & $0.1-0.2$ & \\
\hline $\mathrm{S}\left(\mathrm{Al}_{2} \mathrm{CuMg}\right)$ & $1.0-2.7$ & - & $3.1-6.0$ & $0.3-0.4$ & \\
\hline$\beta\left(\mathrm{Al}_{3} \mathrm{Mg}_{2}\right)$ & $1.15-0.5$ & - & - & $0.8-0.9$ & \\
\hline
\end{tabular}

firms the earlier conclusion about

the most harmful effect of the phases formed by silicon, iron and copper. A relatively new quantitative measure, the phase shape coefficient, $F$, correlates well with the mechanical properties of all the studied alloys. The closer the coefficient to unity, the greater the ductility index of the alloys.

In order to neutralize the negative influence of excess phases, in particular $(\mathrm{Mg}, \mathrm{Si}, \mathrm{Sn}, \mathrm{Pb})$, high-temperature heat treatment was tested on the alloy, which made it possible to obtain high ductility of secondary alloys. Heat

treatment also makes it possible to change the shape of the silicon-containing phases - the phase $(\mathrm{Mg}, \mathrm{Si}, \mathrm{Sn}, \mathrm{Pb})$ fragments during heating for quenching, then coagulates. Moreover, the higher the heating temperature, the faster the processes of fragmentation and coagulation of the phase take place. So, for example, at a temperature of $520^{\circ} \mathrm{C}$, it is enough to withstand the alloys for 1 hour to obtain a globular-shaped morphology. This helps to neutralize the harmful effects of silicon. 


\section{Alloys of the $\mathrm{Al}-\mathrm{Mg}-\mathrm{Sc}$ system}

The main disadvantage of cast alloys from scrap is their low strength characteristics. Therefore, based on an analysis of the results of the studies [15-17] on the study of the phase composition of multicomponent systems, the task was to select the appropriate small additives (not more than tenths of a percent) to preserve the advantages of aluminum alloys with the main alloying element of magnesium.

It is known [18-19] that abnormally supersaturated $\alpha$-Al solid solutions are formed in wrought scandiumalloyed magnelias during soldification. This solid solution, upon subsequent heating of the alloys, decomposes with the formation of a dispersed particles of the $\mathrm{Al}_{3} \mathrm{Sc}$ phase, which are coherent with $\alpha-\mathrm{Al}$ matrix. Therefore, the effect of small addition $(0.1-0.6 \%)$ of scandium on secondary aluminum-based alloys was studied.

Considering that the mining and metallurgical complex of Uzbekistan produces rare-earth metals, the number of which is growing from year to year, an attempt was made to improve the structure of secondary alloys by introducing cerium, yttrium, titanium, cadmium, zirconium in their amount up to $0.35 \%$ by weight of the alloy.

It has been established that the introduction of small additives of these elements (especially scandium, titanium, zirconium) strongly refines the grain structure of the alloys (Fig. 3).

The effect of grain refinement is clearly visible on micrographs. So, if in Fig. 4, $a$, 4 grains are contoured in the plane of the photograph, then the introduction of beryllium (Fig.4, $b$ ) slightly increased the number of grains (up to 6, within the measurement error), the introduction of titanium increased the number of grains on the plane of the microsection significantly - several times (up to 34-42), the introduction of scandium gave the effect of "explosive" (figuratively) grain refinement - more than 160 grains were observed on the plane of the photograph. This grinding leads to an increase in the mechanical pro-
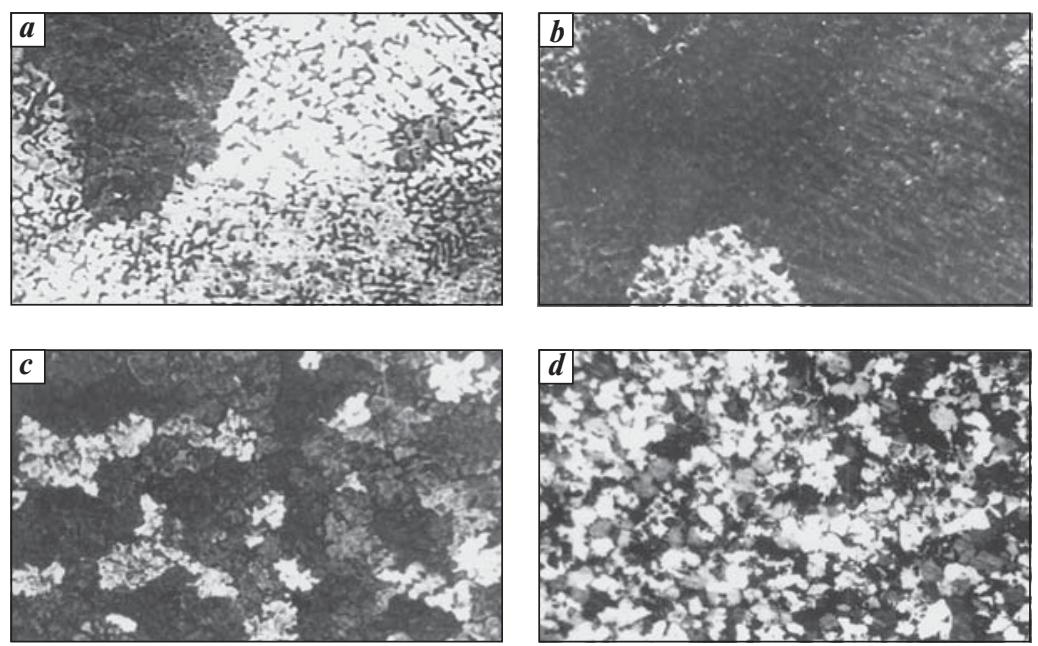

Fig. 4. Grain structure of $\mathrm{Al}+6 \% \mathrm{Mg}$ alloys with impurities at an average level: $a-$ without additives; $b-0.3 \% \mathrm{Be} ; c-0.15 \% \mathrm{Ti} ; d-0.5 \% \mathrm{Sc}$, molten state, $\times 125$ perties of alloys, particularly, plasticity $(\delta)$ up to $10 \%$, depending on the level of impurities.

The presence of many impurities render the studied alloys poor ductility, the index of which, $\delta$, varies from 1.5 to $2 \%$. However, the high cost of scandium does not allow the industrial production of secondary alloys based on the studied system. Alloys of this group can be easily developed in the future based on research results, if the cost of scandium produced by metallurgy in Uzbekistan will be up to $15 \%$ of the cost of aluminum alloys themselves. Therefore, an attempt was made to create an alloy with the main alloying element, being magnesium (4.0-6.0\%), intended for the manufacture of parts by shape casting in metal molds. According to the results of the research, an aluminum-based casting alloy was obtained containing magnesium, silicon, iron and beryllium, characterized in that, in order to increase the ductility and fracture toughness in the as-cast state, it contains components in the following ratio (wt.\%): magnesium $4.0-6.0 \%$, silicon $0.2-0.6 \%$, beryllium $0.15-0.5 \%$, iron $1.0-2.0 \%$, the rest is aluminum. Moreover, the properties of the alloy reached: temporary resistance, $\sigma_{U T S}$, of 170-240 MPa; elongation, $\delta$, of $3-6 \%$, fracture toughness, $\mathrm{KCV}$, of $19-21 \mathrm{MPa} \cdot \mathrm{M}^{1 / 2}$ in the as-cast state and these parameters for this alloy in the heat-treated state reached the values of $180-275 \mathrm{MPa}$, $6-8 \%, 23-26 \mathrm{MPa} \cdot \mathrm{M}^{1 / 2}$, respectively.

\section{Industrial silumins}

A significant place in the total production of foundry aluminum alloys is occupied by heat-resistant complexalloyed eutectic silumins - alloys for pistons of internal combustion engines containing such expensive metals as nickel, copper, magnesium, titanium. A variety of compositions of piston silumins used in different countries, a low culture of recycling scrap aluminum alloys in our country, the lack of consensus in the scientific literature on the effect of alloying elements and impurities on the properties of piston alloys, as well as overdue problems in saving material resources, pointed out the need to study the influence of the main alloying elements and the most important impurities on the structure and properties of piston alloys at room and elevated temperatures. On this basis, it was necessary to recommend the choice of the piston silumin composition optimal from the point of view of the economy of Uzbekistan and its properties. The constructed multicomponent systems, their poly- and isothermal crosssections, the results of metallographic and quantitative micro- $X$-ray spectral analyzes made it possible to divide the intermetallides encountered in the structure of piston silumins into two groups. The first is phases of variable composition, formed based on $\mathrm{Al}_{3} \mathrm{Ni}_{2}, \mathrm{Al}_{7}(\mathrm{CuNi})_{2} \mathrm{Fe}$ and (Al, Fe, Mn, Si) compounds, where copper can replace nickel 
in significant quantities, and iron and manganese can be replaced by nickel, copper and chrome. The first two phases have a branched structure, whilst the third one exhibits the morphology of "fern leaves" with a shape coefficient close to zero. The second group includes intermetallic compounds of constant composition of eutectic origin: $\mathrm{CuAl}_{2} \mathrm{~W}$ and $\mathrm{Mg}_{2} \mathrm{Si}$ with a shape coefficient close to zero. When the iron content is more than $1.2 \%, \beta(\mathrm{Al}$, $\mathrm{Fe}, \mathrm{Si}$ )-phase is formed in the alloy, which has an unfavorable needle-shaped morphology. Taking into account that copper and magnesium affect the alloying of an aluminum-based solid solution, and the remaining elements increase the volume fraction of intermetallic compounds, it is logical to recommend limiting the content of copper and magnesium (in total) in piston silumin to $2-3 \%$, iron and nickel to $1.2 \%$. In the composition of the alloys, it is desirable to introduce small additives of elements that form the eutectic components - transition metals, which can provide satisfactory casting properties of silumins.

Based on the research (and considering the high copper content in the scrap aluminum alloys coming for processing), recommendations are given on optimizing the composition of heat-resistant silumins. Alloys in addition to silicon (4-6\%) may contain copper (3.5-5.5\%) nickel (up to $1.3 \%$ ), manganese (up to $1.2 \%$ ), magnesium (up to $1.4 \%$ ) and impurities of iron (less than 1.5\%), as well as additionally chromium and titanium (up to $0.3 \%$ each).

The established laws, changes in the structure and properties in aluminum alloys with small additives and a high content of impurities can be applied in the process of development and production (in the conditions of the Tashkent plant for the preparation and processing of scrap and non-ferrous metal waste) high-strength, corrosionresistant cast aluminum alloys, such as, for example, alloys based on the $\mathrm{Al}-\mathrm{Mg}-\mathrm{Zn}-\mathrm{Cu}, \mathrm{Al}-\mathrm{Zn}-\mathrm{Mg}-\mathrm{Cu}$ and $\mathrm{Al}-\mathrm{Cu}-\mathrm{Zn}-\mathrm{Mg}$ systems with a high content of iron and silicon impurities (as the most harmful), which are needed for various sectors of the economy of Uzbekistan.

\section{High-strength foundry aluminum alloys}

This group of alloys includes alloys, which include magnesium, zinc, copper in various ratios. Since it was established that the more phases are involved in the eutectic reaction, the more dispersed the structure, it was necessary to recommend just such small additives. The same additives should maximally bind the most harmful impurities of iron and silicon into globular $(F>0.4)$ phases to reduce their volume fraction. And finally, small additives had to form phases with a minimum content of alloying elements - responsible for hardening during aging.

The choice of additives was based on the results of studies presented above in the previous sections of this work. From the point of view of the harmful effects of iron and limitations of its concentration, it has been experimentally proved that $\mathrm{Be}, \mathrm{Co}, \mathrm{Mn}, \mathrm{Ni}$, forming phases rich in iron with a shape factor greater than 0.5 , improve the properties of alloys significantly.

In terms of the harmful effects of silicon, sodium and calcium can form silicon-rich phases. Calcium is most effective, which leads to the formation of the $\mathrm{CaSi}_{2} \mathrm{Al}_{2}$ phase instead of $\mathrm{Mg}_{2} \mathrm{Si}$. Consequently, magnesium remains in the solid solution, which, in turn, allows the use of a low-grade charge in the production of high-strength aluminum based on the $\mathrm{Al}-\mathrm{Zn}-\mathrm{Mg}-\mathrm{Cu}$ system.

Practical recommendations for alloying high-strength alloys are also based on the results of works [20-22] on improving the structure and properties of aluminum alloys.

In accordance with the localization program of industrial production and the state order from the waste of aluminum alloys of the main production of the mechanical plant, the rocker arm, disk cups, crosspieces and rocking arms of table scales were made.

\section{Conclusions}

The results of scientific research and experience in working with scrap aluminum alloys made it possible to develop a draft Republican standard "Cast aluminum alloys. Technical conditions"; draft Republican standard "Scrap and waste of aluminum and its alloys"; project "Technological regulations to produce secondary aluminum alloys". In the conditions of JSC Uzvtortsvetmet, experimental melting of secondary aluminum alloys was carried out, the results of which are consistent with a government decree to improve the collection, preparation and processing of scrap, nonferrous metal waste.

\section{References}

1. Belov N. A. Phase Composition of Industrial and Prospective Aluminium Alloys. Moscow: Publishing House MISiS, 2010. $511 \mathrm{p}$.

2. Belov N. A., Phase Composition of Aluminum Alloys. Moscow: Publishing House MISiS, 2009. 392 p.

3. Zolotorevsky V. S., Belov N. A. Metal Science of Cast Aluminium Alloys. Moscow: Publishing House MISiS, 2005. 376 p.

4. Gusarov M. N., Mansurov Yu. N. Dependence of the Mechanical Properties of Alloys of the $\mathrm{Al}-\mathrm{Mg}$ System with a High Content of Impurities on the Cooling Rate During Crystallization. Tsvetnye Metally. 1988. No. 2. pp. 69-71.

5. Belov N. A. Computer Analysis of Multicomponent State Diagrams. Moscow: Publishing House MISiS, 2003. 47 p.

6. Mansurov Yu. N., Kurbatkina E. I. Buravlev I. Yu., Reva V. P. Features of structure's formation and properties of composite aluminum alloy ingots. Non-Ferrous Metals. 2015. No. 2. pp. 40-47. DOI: $10.17580 / \mathrm{nfm} .2015 .02 .08$

7. Mansurov Yu. N., Belov N. A., Sannikov A. V., Buravlev I. Yu. Optimization of Composition and Properties of Heat-Resistant Complex-Alloyed Aluminum Alloy Castings. Non-Ferrous Metals. 2015. No. 2. pp. 48-55. DOI: 10.17580/nfm.2015.02.09

8. Zolotorevskiy V. S., Belov N. A., Glazoff M. V. Casting Aluminum Alloys. Elsevier Science, 2007. 544 p. 
9. Appel F., hring M., Paul J. D. H., Lorenz U. Design, Properties and Processing of Novel TiAl Alloys. Proceedings of the $2^{\text {nd }}$ International Symposium on Structural Intermetallics. The Minerals, Metals and Materials Society, Warrendale, PA, 2001. pp. $63-72$.

10. Raghavan V. Al-Cu-Ti (Aluminum - Copper - Titanium). Journal of Phase Equilibria \& Diffusion. 2006. Vol. 27, Iss. 2. pp. $156-157$.

11. Raghavan V. Al-Ni-Ti (Aluminum - Nickel - Titanium). Journal of Phase Equilibria \& Diffusion. 2010. Vol. 31, Iss. 1. pp. 55-56.

12. Polmear I., Light Alloys: from Traditional Alloys to Nanocrystals. $4^{\text {th }}$ ed. Elsevier Butterworth-Heinemann, 2006. 421 p.

13. Mansurov Yu. N., Kadyrova D. S., Rakhmonov J. Dependence of Corrosion Resistance for Aluminum Alloys with Composition Increased Impurity Content. Metallurgist. 2019. Vol. 62, Iss. 11-12. pp. 1181-1186.

14. Mansurov Yu. N., Rakhmonov J. U. Analysis of the Phase Composition and the Structure of Aluminum Alloys with Increased Content of Impurities. Non-Ferrous Metals. 2018. No. 2. pp. 37-42. DOI: 10.17580/nfm.2018.02.07.

15. Todaka Y., Umemoto M., Yamazaki A., Sasaki J., Tsuchiya K. Influence of High-Pressure Torsion Straining Conditions on Microstructure Evolution in Commercial Purity Aluminum, Materials Transactions. 2008. Vol. 49, Iss. 1. pp. 7-14.

16. Yang Y., Chen Y., Ma F., Hu H., Zhang Q., Tang T., Zhang X. Microstructure Evolution of 1050 Commercial Purity
Aluminum Processed by High-Strain-Rate Deformation. Journal of Materials Engineering and Performance. 2015. Vol. 24, No. 11. pp. 4307-4312.

17. Kamikawa N., Huang X., Tsuji N., Hansen N. Strengthening Mechanisms in Nanostructured High-Purity Aluminum Deformed to High Strain and Annealed. Acta Materialia. 2009. Vol. 57, Iss. 14. pp. 4198-4208.

18. Sabirov I., Murashkin M. Y., Valiev R. Z. Nanostructured Aluminium Alloys Produced by Severe Plastic Deformation: New Horizons in Development. Materials Science and Engineering: A. 2013. Vol. 560. pp. 1-24.

19. Petrova A. N., Brodova I. G., Razorenov S. V. Strength Properties and Structure of a Submicrocrystalline $\mathrm{Al}-\mathrm{Mg}-\mathrm{Mn}$ Alloy under Shock Compression. Physics of Metals and Metallography. 2017. Vol. 118, Iss. 6. pp. 601-607.

20. Estrin Y., Vinogradov A. Extreme Grain Refinement by Severe Plastic Deformation: a Wealth of Challenging Science. Acta Materialia. 2013. Vol. 61, Iss. 3. pp. 782-817.

21. Popova E. A., Kotenkov P. V., Shubin A. B., Pastukhov E. A. The Al-Sc-Y, Al-Zr-Y Master Alloys for Modification and Doping of Aluminum Alloys. Journal Melts. 2015. No. 2. pp. 53-59.

22. Zhao J.-W., Luo B.-H., He K.-J., Bai Z.-H., Li B., Chen W. Effects of Minor $\mathrm{Zn}$ Content on Microstructure and Corrosion Properties of Al-Mg Alloy. Journal of Central South University. 2016. Vol. 23, Iss. 12. pp. 3051-3059. 